\title{
Determinants of the Effectiveness of Online Learning among University Students during Covid-19 Crisis
}

Noorain Mohd Nordin, Wei-Loon Koe, Munirah Mohamed, Norraeffa Md Taib, Nur Arifah Sapuan

To Link this Article: http://dx.doi.org/10.6007/IJARBSS/v11-i5/10010

DOI:10.6007/IJARBSS/v11-i5/10010

Received: 06 March 2021, Revised: 10 April 2021, Accepted: 28 April 2021

Published Online: 21 May 2021

In-Text Citation: (Nordin et al., 2021)

To Cite this Article: Nordin, N. M., Koe, W.-L., Mohamed, M., Taib, N. M., \& Sapuan, N. A. (2021). Determinants of the Effectiveness of Online Learning among University Students during Covid-19 Crisis. International Journal of Academic Research in Business and Social Sciences, 11(5), 560-568.

\section{Copyright: (c) 2021 The Author(s)}

Published by Human Resource Management Academic Research Society (www.hrmars.com)

This article is published under the Creative Commons Attribution (CC BY 4.0) license. Anyone may reproduce, distribute, translate and create derivative works of this article (for both commercial and non-commercial purposes), subject to full attribution to the original publication and authors. The full terms of this license may be seen

at: http://creativecommons.org/licences/by/4.0/legalcode

Vol. 11, No. 5, 2021, Pg. 560 - 568

Full Terms \& Conditions of access and use can be found at http://hrmars.com/index.php/pages/detail/publication-ethics 


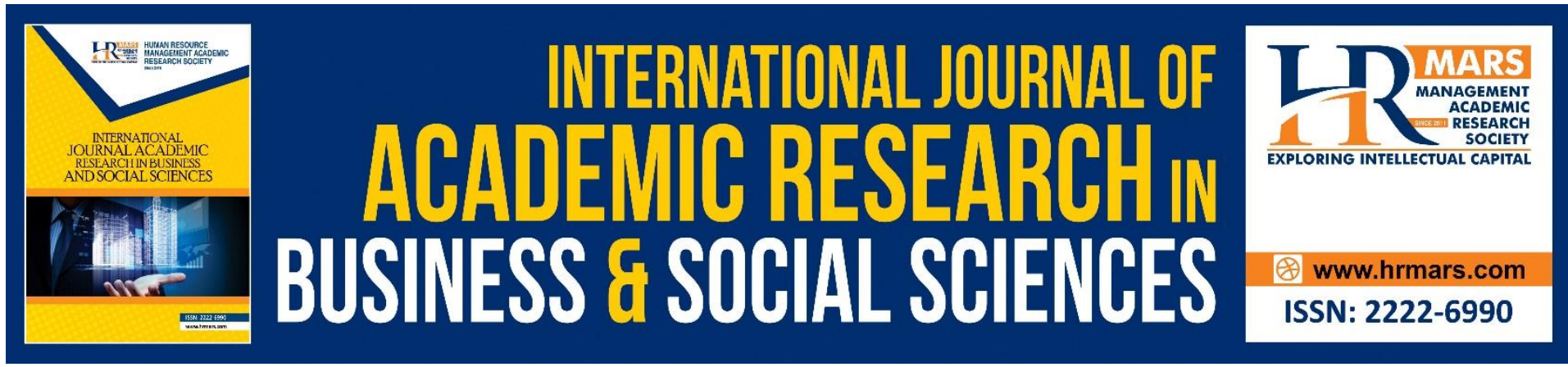

\title{
Determinants of the Effectiveness of Online Learning among University Students during Covid-19 Crisis
}

\author{
Noorain Mohd Nordin, Wei-Loon Koe, Munirah Mohamed, \\ Norraeffa Md Taib, Nur Arifah Sapuan \\ Faculty of Business and Management, Universiti Teknologi Mara, Cawangan Melaka
}

\begin{abstract}
Higher Learning Institution around the world has been directly and indirectly affected due to the Covid-19 pandemic. The whole globe was affected by the Coronavirus disease (COVID19), which caused a major disruption in every economy sector as well as the education sector. In Malaysia, the traditional face-to-face learning has been replaced by online learning to ensure education continuity. Therefore, this study aims to determine the relationship between student readiness, instructor characteristics and psychology of learning on the effectiveness of online learning during Covid-19 among higher university students from selected public university in Malaysia and to measure the predictor of the effectiveness of online learning. This study is quantitative in the form and questionnaires distributed to collect information from respondents based on the size of 114 sample size and use convenience sampling method. The data obtained through questionnaires is analyzed and evaluated by correlation and regression testing. Most of the results show low and moderate relationship on the effectiveness of online learning during Covid-19. Finally, limitation of study is also recognized and identified after the research is done. There are recommendations to the university and the correspondent for future research to be conducted for better understanding in future.
\end{abstract}

Keywords: Online Distance Learning, Student Readiness, Instructor Characteristics Psychology of Learning and Covid-19.

\section{Introduction}

The global disruption by Coronavirus disease (COVID-19) caused by a newly discovered coronavirus (World Health Organization (WHO), 2020 has severely affected the economy sector of every nation in this world, including the higher education sector. Higher education was significantly affected by this disease faced major changes that impacted the students in higher education sector. The education system in Malaysia faced many challenges during the pandemic period of Covid-19 same as the other countries. The education system in Malaysia all this while and how it has been affected by the Covid-19 pandemic period will be discussed in this particular part mainly. The covid-19 pandemic brought in many changes in the learning system. The learners were all restricted from attending the physical classes due to the 
implementation of the lockdown (Ahmad et al., 2019). Every aspect of the life of the common people was affected majorly due to the pandemic period of Covid-19 (Shahzad et al., 2020).

Moreover, the changes which occurred due to the pandemic period affected the educational practices. The Education sectors are the major part to endure the negative impacts of the process of movement control order or lockdown. All of the schools and the educational sectors were closed during this phase (Othman, Kadar, Umar, \& Ahmad, 2020). During the pandemic of Covid-19 in many other countries such as China, South Korea, Italy and Iran have developed the home schooling temporarily for millions of learners and it has been very inconvenient for the learners. They had faced immense difficulties due to online schooling (Zhao et al., 2020). Many countries have developed the home schooling with the cooperation of the schools and the education sectors (Brom et al., 2020). This study will help the learners to plan their learning accordingly from the factors given in this study so that can avoid those barriers and learn in an effective way. An effective way of learning will be always be the first choice for the learners because it makes their life easier. By finding out those factors, future researchers will be able to conduct a research study to find out the effectiveness level of those factors and work on to find the solutions.

\section{Literature Review}

\section{Online Learning in Malaysia}

The Malaysian Higher Learning Institutions had implemented online learning started in the late 1990s (Hussin et al., 2009). The online learning demand has been increasing due to the capability to reach global audiences, unique functionality, accessibility, and flexibility in the long run (Azhari and Ming, 2015). In line with the educational developments, the Malaysian Ministry of Education under the Malaysian Education Blueprint 2015-2025 (Higher Education) has introduced initiatives in making the online learning as an integral component of higher education and lifelong learning (Malaysian Education Blueprint 2015-2025 (Higher Education): E-16). As the usage of online learning is not something new and has gain a lot of attention from other researchers, there are many researches carried out by the academicians on the effectiveness of online learning. Even though online learning is not something that will be practicing fully in learning environment as many students prefer "face-to-face" class, but it cannot be ignored that online learning has its own importance in the learning process itself especially during Covid time.

In Malaysia, open distance education has been established since the year 1995 and has seen rapid growth due to government attempt in establishing information-rich society and a knowledge-based economy (Kaur, and Ahmed, 2006). Even though at the first distance education is been introduced, not all public universities began offering the programs. But, as for today, almost all universities and institutions in Malaysia are offering the distance education programs. There are a large number of studies that could show the positive statistically relevant results of online learning for students as opposed to the conventional "face-to-face" model. Navarro and Shoemaker (2000) also find that online learner learning outcomes were as good as or even better than conventional learners given the context features and the students were also very pleased with online learning itself. While positive results for the effectiveness of online learning have been shown in the studies, it is still uncertain if this generally stands true throughout studies. Despite the growth in both size and 
acceptance of distance education, it cannot be helped that there is still persistent criticism especially in terms of educational delivery.

\section{Student Readiness}

In order for online learning to be fully applied to its full potential and being the most effective learning platform in this digitalized era, the students' readiness is one thing that should be taken into consideration. Each of the students has their own style and preferences when it comes to learning. Tuntirojanawong (2013) agreed that the students or learners must have their own learning style that lead to their success and one must exhibit qualities of selfdetermination and an overall strive for excellence. If these kinds of qualities are lacking, the learner must be facing some struggle to move forward throughout the experience due to cannot cope with many high demands.

Demir Kaymak and Horzum (2013) discovered that indeed there is positive relationship between students' readiness and the effectiveness of online learning. They also stated that there are other factors that mainly affecting the effectiveness of online learning besides readiness such as learning style, strategy approaches and technology use skill. However, among all these factors, it is proven that readiness stands out the most. Unfortunately, even though there are many studies done on online learning, but there are almost no studies focus on the relationship of students' readiness with online learning. Thus, Demir Kaymak and Horzum (2013) research was formed on the assumption that online learning readiness rates are significant predictors of the perceived structure of online learners.

\section{Instructor Characteristics}

In higher education, online education became popular and emerged as an opportunity to offer full online education especially as the technology keep on being developed from years to years. Online education has also arisen and has become one of the alternatives or at least a significant addition to the conventional teaching and learning methods (Lewis and Massey (2003). Ahmad.et al (2019) discovered that one of the reasons why people doubt online learning is because regarding instructor performance and student-instructor interaction. Several studies conducted by previous researchers discovered that strong educator presence along with the quality of course contents are the key elements in courses that facilitate online student engagement and learning successfully (Swan et.al, 2014). In order to establish educator or instructor presence in online courses, it can be achieved in various ways, such as through regular communication with students, consistent feedback and critical discourse modeled by the educator (Gray and Diloreto, 2016).

One of the important things that should be considered in online learning is the students should feel connected to the instructors, with other students within the course and to the course content (Southard et al., 2015). This can be achieved through a supportive learning environment in which the educators strategically combine all medium such as audio, video, synchronous and asynchronous, discussions, practical activities and other online tools to engage students (Gray and Diloreto, 2016). Other study conducted by Nortvig et al. (2018) also proves that there is positive relationship between instructor characteristics and the effectiveness of online distance learning among university students. Nortvig et al. (2018) proposed that educator presence in online settings and interaction between educators and students really influence the effectiveness of online learning. 


\section{Psychology of Learning}

Psychology of learning really helps the instructors in understanding the attitude of the students especially in adapting the online learning environment. This is because, the area of psychology of learning are more concerned towards how the students acquired the skills, how to make the learning more effective, and what factors that help the learning process. Psychology of learning comes in handy as it shows that factors such as motivation and interest indeed have influence on the effectiveness of learning (Aggarwal, 2004). Muilenburg and Berge (2005) discovered that poor motivation is one of the factors that contribute in the high number of dropouts among students from online courses. Schunk (2008) also discovered that students who are motivated are more likely to undertake challenging activities, to be actively engaged and most importantly, able to adopt and enjoy a deep approach to learning and to show improved performance, persistence and creativity. Thus, it shows that if the students are feeling motivated enough to learn, and have the will to learn through online learning medium, online distance learning will be more likely to be more effective. This shows that psychology of learning through motivation will influence the effectiveness of online distance learning.

Moreover, psychology of learning factors such as motivation and students' attitude will be more likely influence students' satisfaction with online learning as well. According to Cakir et.al (2018), there are many reasons why students feel satisfied or dissatisfied with online learning and one of it is due to their motivation level. They also agreed that one of the reasons why their motivation level is low because of lack of interaction and negative perceptions and their dependence on conventional education. Cakir et al. (2018) found that students with high motivation are most likely to stay in the program as Harandi (2015) prove that indeed there is significant relationship between students completing a course with motivation. In a research that was conducted by Han and Hiver (2018), has mentioned that the learners lost their motivation during the learning of the pandemic period (Covid-19 pandemic) and especially in the skill of writing in English Language. Furthermore, the English Language could not be learned by some of the learners and achieve the proficiency level which cause the emotional turmoil for the learners (Clyne, 2002). Moreover, the distance learning does effect on the cognitive styles and the information processing system and the learners who were not able to keep up with it had lack of motivation and felt extremely demotivated to further on the language learning (Chen \& Hsu, 2020).

\section{Research Methodology}

Data had collected from the sample using the validated and reliable research instrument. After the data had collected, they had analyzed using correlation and multiple regression analysis. Correlation analysis was used to determine the relationship between the independent and dependent variables, while multiple linear regression analysis was used to determine the contributions of each of the significant predictors or independent variables towards the dependent variable.

Target populations of this study are the students from selected public universities in Malaysia as the respective respondents. From this statement, 114 respondents have been chosen to represent the total population of the students. For this research, the sampling method that will be use by researcher is convenience sampling under non-probability technique. The research instrument that has been use in this study is questionnaire. The questionnaires that has used in this research study will be classified into five section and other several parts. 
First, Section A comprises the demographic background of the respondents. It consists of gender, age, name of university of the respondents. Next, Section B is aimed to examine and evaluate the dependent variable and independent variable. The sources of the constructed instrument used on this research study were adopted from Muilenburg and Berge (2005) for online learning, while student readiness Kalz et al. (2017), instructor characteristics Olson et al. (2005) and psychology of learning (Kalz et al. (2017). The data were analysed using the SPSS reliability and, the Cronbach's Alpha coefficient of reliability was derived. The reliability index Cronbach's Alpha of the instrument for online learning was 0.828 while for independent variables which consist of student readiness (0.832), instructor characteristics (0.858), and psychology of learning (0.707).

\section{Findings}

The study identified a relationship among the determinants (student readiness, instructor characteristics and psychology of learning) with the effectiveness of online learning during covid-19 time. In achieving this, Pearson $r$ correlation coefficients between each pair of variables had examined. As showed in Table 1 , student readiness $(r=0.526)$ at the 0.5 level of significance were positively with moderate relationship with the effectiveness of online learning. While instructor characteristics factor result showed $(r=0.366)$ with $(\rho=0.000)$ and psychology of learning $(r=0.385)$ with $(p=0.000)$ which is less than 0.05 indicates that there was significance, and the R-value showed low relationship. This is shown through the result where the independent variable of student readiness, instructor characteristics and psychology of learning had significantly affected the dependent variable with the effectiveness of online learning during covid-19-time crisis.

Table 1: Pearson Correlation Coefficient Student Readiness, Instructor Characteristics, Psychology of Learning

\begin{tabular}{lcc} 
Variables & R-value & Result \\
\hline $\begin{array}{l}\text { Student Readiness } \\
\text { Instructor }\end{array}$ & 0.526 & Moderate Relationship \\
Characteristics & 0.366 & Low Relationship \\
Psychology of Learning & 0.385 & Low Relationship \\
\hline
\end{tabular}

As shown in Table 2, the value of $\mathrm{R}^{2}=0.305$ this indicates that $30.5 \%$ of the variance determinants of effectiveness on online learning is influenced by independent variables of this study which are student readiness, instructor characteristics and psychology of learning. Consequently, $69.5 \%$ of the variance in effectiveness on online learning is explained by other factors. The results shown, student readiness was the most significant predictor variable that contribute to the effectiveness on online learning during covid-19 with the value of $(\beta=0.458)$ or $45.0 \%$ and significant at 0.000 . The significance level for students' readiness also less than $5 \%$ significance level which is 0.000 , means that students' readiness is significant and explain that students' readiness is positively related with online learning supported by Demir Kaymak and Horzum (2013), found that there is a positive significant relationship between the students' readiness and the effectiveness of online learning.

For the second independent variable, instructor characteristics, is recorded with $(\beta=$ -0.187) with $(\rho=0.043)$ which is less than 0.05 . This is the second highest value after students' readiness and it shows that instructor characteristics also have influence on online learning. Lastly, from the tables shown, psychology of learning recorded with the lowest value of Beta 
coefficient which is $(\beta=-0.011)$ and the significance level also exceed $5 \%$ significance level with 0.920 . Therefore, it shows that psychology of learning is not significant on online learning and has no influence on the dependent variable as well. It could be concluded, based on the results obtained from the analysis students' readiness has the highest influence on the effectiveness on online learning and followed by instructor characteristics. However, the last independent variable which is psychology of learning was not support the dependent variable.

Table 2: Regression Analysis Summary for Effectiveness Online Learning

\begin{tabular}{lccc} 
Variables & Standardized Coefficient $(\boldsymbol{\beta})$ & Sig. & $\mathbf{R}^{\mathbf{2}}$ \\
\hline & & 0.000 & 0.305 \\
(Constant) & 0.458 & 0.000 & \\
Student Readiness & & & \\
Instructor & -0.187 & 0.043 & \\
Characteristics & -0.011 & 0.920 & \\
Psychology of Learning & & & \\
\hline
\end{tabular}

\section{Conclusion}

Throughout this research study, it was found that there was a similar and differences in the results between the present study and the past one. The different outcomes can be resulted from so many reasons. This study is conducted because of the new norms that university students currently has to face which is the need of having online learning instead of the usual traditional learning. The world is currently facing with the biggest obstacles that hinder all kind of activities from being practiced as usual, which is Covid-19. Due to these pandemic issues, all of the students and the instructor or educators have no choice but to practice this online learning platform.

However, it is not easy for all to suit with this new norm as both the students and the instructors have been comfortable with the traditional way. Having to change from having class in a classroom to having a class in front of the laptop is not easy. Thus, many people that are being involved in this kind of situation starts to doubt the effectiveness of the online learning. Even though online learning is one of the learning platforms that are rarely been used, but the effectiveness of this platform is beyond than what people always assume. In order to make online learning as effective as it can, this study will act as a purpose in determining the factors of the effectiveness of online learning.

The finding showed only two of them has significant relationship with online learning effectiveness which is students' readiness and instructor characteristics. However, as for the third independent variable which is psychology of learning, no important association with the dependent variable has been proved. Thus, the hypothesis for the third independent variable is not supported. Nevertheless, the researcher's result for this study has been supported with the previous research as well. Meaning that, this research shows that it is providing the valid and reliable information for the future research. The future researcher also could identify more variables that are more appropriate and significance to the study. This will lead to the new era of education system in Malaysia to suit with current situation during Covid-19 time.

\section{Acknowledgement}

The author would like to thank the Universiti Teknologi Mara Cawangan Melaka and coauthors that have helped in conducting and completing this research. 


\section{Corresponding Author}

Noorain Mohd Nordin, Universiti Teknologi Mara, Cawangan Melaka, Malaysia

Email: noorainnordin@uitm.edu.my

\section{References}

Aggarwal, P. (2004). The Effects of Brand Relationship Norms on Consumer Attitudes and Behavior. Journal of Consumer Research, 31(1), 87-101. https://doi.org/10.1086/383426

Ahmad, M. K., Adnan, A. H. M., Azamri, N. M., Idris, K. B., Norafand, N. N., \& Ishak, N. I. (2019). Education 4.0 technologies for English language teaching and learning in the Malaysian context. Paper presented at the Proceedings of the International Invention, Innovative \& Creative (InIIC) Conference, Series.

Azhari, F. A., \& Ming, L. C. (2015). Review of e-learning Practice at the Tertiary Education level in Malaysia. Indian Journal of Pharmaceutical Education and Research, 49(4), 248-257. https://doi.org/10.5530/ijper.49.4.2

Brom, C., Lukavský, J., Greger, D., Hannemann, T., Straková, J., \& Švaříček, R. (2020). Mandatory Home Education During the COVID-19 Lockdown in the Czech Republic: A Rapid Survey of 1st-9th Graders' Parents. Paper presented at the Frontiers in Education.

Cakir, O., Karademir, T., \& Erdogdu, F. (2018). Psychological Variables Of Estimating Distance Learners' Motivation. Turkish Online Journal of Distance Education, 19(1), 163-182. https://doi.org/10.17718/tojde.382795

Chen, Y.-L., \& Hsu, C.-C. (2020). Self-regulated mobile game-based English learning in a virtual reality environment. Computers \& Education, 103910.

Cheung, T., \& Yip, P. (2015). Depression, Anxiety and Symptoms of Stress among Hong Kong Nurses: A Cross-sectional Study. International Journal of Environmental Research and Public Health, 12(9), 11072-11100. https://doi.org/10.3390/ijerph120911072

Clyne, S. (2002). Psychological factors in second language acquisition: Why Your international students are sudando la gota gorda (Sweating Buckets). Retrieved January, 5, 2003.

Kaymak, D. Z., \& Horzum, M. B. (2013). Relationship between online learning readiness and structure and interaction of online learning students. Educational Sciences: Theory and Practice, 13(3), 1792-1797.

Gray, J. A., \& DiLoreto, M. (2016). The effects of student engagement, student satisfaction, and perceived learning in online learning environments. International Journal of Educational Leadership Preparation, 11(1), n1.

Han, J., \& Hiver, P. (2018). Genre-based L2 writing instruction and writing-specific psychological factors: The dynamics of change. Journal of Second Language Writing, 40, 44-59.

Harandi, S. R. (2015). Effects of e-learning on Students' Motivation. Procedia-Social and Behavioral Sciences, 181, 423-430.

Hussin, H., Bunyarit, F., \& Hussein, R. (2009). Instructional design and e-learning. CampusWide Information Systems, 26(1), 4-19. https://doi.org/10.1108/10650740910921537

Kalz, M., Khalil, M., \& Ebner, M. (2017). Editorial for the special issue on advancing research on open education. Journal of Computing in Higher Education, 29(1), 1-5. https://doi.org/10.1007/s12528-017-9143-3 
Kaur, A., \& Ahmed, A. (2006). E-LEARNING CHALLENGES AS PERCEIVED BY COMMUNITIES OF PRACTICE: OPEN UNIVERSITY MALAYSIA'S EXPERIENCES. Asian Association of Open Universities Journal, 2(1), 51-65. https://doi.org/10.1108/aaouj-02-01-2006-b006

Lewis, K., \& Massey, C. (2003). Delivering enterprise education in New Zealand. Education+ Training.

Ministry of Education Malaysia (MoE) (2015) Malaysia Education Blueprint 2015-2025 (higher education). Putrajaya: Author.

Muilenburg, L. Y., \& Berge, Z. L. (2005). Student barriers to online learning: A factor analytic study. Distance Education, 26(1), 29-48. https://doi.org/10.1080/01587910500081269

Navarro, P., \& Shoemaker, J. (2000). Performance and perceptions of distance learners in cyberspace. American Journal of Distance Education, 14(2), 15-35. https://doi.org/10.1080/08923640009527052

Nortvig, A. M., Petersen, A. K., \& Balle, S. H. (2018). A Literature Review of the Factors Influencing E-Learning and Blended Learning in Relation to Learning Outcome, Student Satisfaction and Engagement. Electronic Journal of E-learning, 16(1), pp46-55.

Olson, E. M., Slater, S. F., \& Hult, G. T. M. (2005). The performance implications of fit among business strategy, marketing organization structure, and strategic behavior. Journal of marketing, 69(3), 49-65.

Othman, J., Kadar, R., Umar, N., \& Ahmad, N. (2020). Covid-19 Pandemic Effects In Teaching And Learning Methods During Movement Control Order (MCO). Volume 1, September 2020, 1.

Schunk, D. H. (2008) Metacognition, Self-Regulation, and Self-Regulated Learning: Research Recommendations. Educ Psychol Rev 20, 463-467

Southard, S., Meddaugh, J., \& France-Harris, A. (2015). Can SPOC (Self-Paced Online Course) live long and prosper? A comparison study of a new species of online course delivery. Online Journal of Distance Learning Administration, 18(2).

Shahzad, S. K., Hussain, J., Sadaf, N., Sarwat, S., Ghani, U., \& Saleem, R. (2020). Impact of Virtual Teaching on ESL Learners' Attitudes under COVID-19 Circumstances at Post Graduate Level in Pakistan. English Language Teaching, 13(9), 1-9.

Swan, K., Day, S. L., Bogle, L. R., \& Matthews, D. B. (2014). A collaborative, design-based approach to improving an online program. The Internet and Higher Education, 21, 7481.

Tuntirojanawong, S. (2013). Students' Readiness for E-Learning: A Case Study of Sukhothai Thammathirat Open University, Thailand. Journal of Learning in Higher Education, 9(1), 59-66.

Zhao, Y., Guo, Y., Xiao, Y., Zhu, R., Sun, W., Huang, W., . . Zhu, D. (2020). The Effects of Online Homeschooling on Children, Parents, and Teachers of Grades 1-9 During the COVID19 Pandemic. Medical Science Monitor: International Medical Journal of Experimental and Clinical Research, 26, e925591-925591. 